\title{
PENGARUH KARAKTERISTIK PETANI, MOTIVASI PETANI DAN PERAN PENDAMPING TERHADAP PERILAKU PETANI PENANGKAR DALAM MENDUKUNG KETERSEDIAAN BENIH PADI DI KABUPATEN TABANAN
}

\author{
The Effects of Farmers Characteristics, Motivation and The Role of Assistant \\ on The Behavior of Breeder Farmers to Support The Availability of Rice Seeds \\ in the District of Tabanan
}

\author{
I Putu Adi Purwanta*, I Dewa Putu Oka Suardi, I Ketut Surya Diarta.
}

Program Studi Magister Agribisnis, Fakultas Pertanian, Universitas Udayana, Bali, Indonesia.

*Email: putu130379@gmail.com

\begin{abstract}
Seed is essential support farming success. Availability it required support agricultural development. The purpose this study to analyze direct and indirect effects farmers characteristics, motivation and role of assistant on the behavior breeder farmers and their influence on the availability rice seeds. The study conducted in Tabanan Regency. Data collection done from March to June 2019. The number of population 142 rice breeders with respondent 59 rice breeders. The number of respondents determined using Slovin formula. Analysis tool used SmartPLS version 3.0. The results of study showed farmers characteristics, motivation, and role of assistant had a significant effect on the behavior breeder farmers. Moreover, seed availability was affected by role of assistant, yet farmers characteristics and motivation had no notable effect on it. However, the indirect influence farmers characteristics, motivation and role of assistant not significant to seed availability through the behavior breeder farmers. From this study, it's suggested that 1) to maintain availability rice seeds in Tabanan Regency, role of assistant for farmers cultivate in own fields is optimized according to their respective duties and functions. 2) Role of assistant are role subak, PPL, BPSBTPH, breeders, and the local agriculture office 3) To improve the financial ability local breeders to buy prospective seeds produced by breeder farmers.
\end{abstract}

Keywords: characteristics, motivation, role of assistant, farmer's behavior, seeds

\begin{abstract}
ABSTRAK
Benih menjadi penting karena mendukung keberhasilan usaha tani. Ketersediaan benih berkualitas sangat diperlukan dalam mendukung pembangunan pertanian. Tujuan penelitian ini adalah menganalisis pengaruh langsung dan tidak langsung dari karakteristik petani, motivasi petani dan peran pendamping terhadap perilaku petani penangkar serta pengaruhnya terhadap ketersediaan benih padi. Penelitian dilakukan di Kabupaten Tabanan sebagai sentra produksi padi di Bali. Pengumpulan data dari bulan Maret sampai dengan Juni 2019. Jumlah populasi sebanyak 142 petani yang mengerjakan penangkaran benih di lahan sendiri dengan responden sebanyak 59 petani penangkar yang ditentukan menggunakan rumus Slovin. Alat analisis yang digunakan SmartPLS versi 3.0. Hasil penelitian menunjukkan bahwa karakteristik petani, motivasi petani dan peran pendamping berpengaruh signifikan terhadap perilaku petani penangkar. Karakteristik petani, motivasi petani dan perilaku petani penangkar berpengaruh tidak signifikan tehadap ketersediaan benih padi. Peran pendamping berpengaruh signifikan terhadap ketersediaan benih. Sedangkan pengaruh tidak langsung dari karakteristik petani, motivasi petani dan peran pendamping tidak signifikan terhadap ketersediaan benih melalui perilaku petani penangkar. Saran yang dapat diberikan yaitu: 1)Untuk menjaga ketersediaan benih padi di Kabupaten Tabanan maka peran pendamping bagi petani yang menangkar di lahan sendiri dioptimalkan sesuai dengan tugas dan fungsi masing-masing. 2)Peran pendamping adalah peran subak, PPL, BPSBTPH, Produsen benih, dan Dinas Pertanian di wilayah penangkaran benih sehingga produksi dan ketersediaan benih dengan enam tepat (tepat varietas, tepat mutu, tepat waktu, tepat jumlah, tepat tempat dan tepat harga) bisa tercapai. 3)Meningkatkan kemampuan penangkar lokal dalam membeli calon benih yang dihasilkan oleh petani-petani penangkar untuk diproses menjadi benih bersertifikat.
\end{abstract}

Kata kunci: karakteristik, motivasi, peran pendamping, perilaku petani, benih 


\section{PENDAHULUAN}

Benih merupakan bagian dari subsistem input dalam sistem agribisnis. Benih yang berkualitas menjadi penting karena mendukung keberhasilan usaha tani. Ketersediaan dan pemanfaatan benih berkualitas sangat diperlukan guna mendukung program ketahanan pangan dan pembangunan pertanian. Varietas unggul baru dapat meningkatkan produksi baik dalam jumlah, mutu serta daya saing produk.

Hingga saat ini 259 varietas padi telah dihasilkan terdiri dari: 198 jenis varietas padi untuk lahan sawah, 22 varietas padi untuk lahan rawa, 20 varietas padi untuk lahan kering dan 19 varietas padi hibrida untuk lahan sawah (Badan Litbang Pertanian, 2018) namun belum semuanya dikembangkan oleh petani dengan berbagai alasan. Salah satu penyebabnya adalah kurangnya ketersediaan benih sumber bersertifikat dari kelas benih penjenis, benih dasar dan benih pokok secara tepat sesuai dengan kebutuhan masyarakat tani.

Berdasarkan permasalahan dan adanya perubahan lingkungan strategis yang terjadi, arah ke depan sistem perbenihan nasional adalah membangun industri benih dengan mendorong peran dominan swasta (BUMN/BUMD) dalam produksi dan peredaran skala komersial melalui penguatan peran swasta dalam produksi dan peredaran benih strategis dengan berbasis sumber daya lokal.

Mosher (1965), menyatakan syarat mutlak yang harus ada dalam pembangunan pertanian adalah adanya pasar untuk hasil usaha tani, teknologi yang senantiasa berkembang, tersedianya bahan dan alat produksi secara lokal, adanya perangsang produksi bagi petani dan tersedianya pengangkutan yang lancar dan kontinu. Untuk menciptakan stabilitas, khususnya ketersediaan benih padi, maka produksi harus didekatkan kepada petani pengguna dengan menumbuhkan penangkar-penangkar benih lokal sehingga benih tersedia secara tepat (tepat varietas, jumlah, mutu, lokasi, waktu dan harga) sesuai dengan harapan petani atau pengguna.

Ketersediaan benih padi yang sesuai dengan keinginan petani masih sulit di peroleh saat musim tanam disebabkan produksi tidak sesuai dengan varietas yang diinginkan oleh petani pengguna. Produksi benih juga tidak tepat waktu dengan musim tanam terkait dengan jadwal tanam di masing-masing subak, ketersediaan air untuk pengolahan lahan serta kebiasaan lainnya yang ada di lingkungan subak. Permasalahan lain yang timbul adalah Calon Benih Kering Sawah (CBKS) dari petani penangkar tidak bisa diproses menjadi benih karena tidak memenuhi kualitas yang diinginkan sehingga harus diolah menjadi beras. Di samping itu produksi benih dalam menjamin ketersediaan benih secara berkelanjutan harus direncanakan dengan baik paling tidak dua tahun sebelumnya.
Kebutuhan benih berdasarkan perkembangan luas tanam kegiatan Upsus di Bali dari tahun 2015 sampai dengan tahun 2018. Tahun 2015 dengan luas tanam 129.801 ha dengan kebutuhan benih $3.245,03$ ton. Tahun 2016 luas tanam 157.064 ha dengan kebutuhan benih 3.926,6 ton. Tahun 2017 luas tanam 143.749 ha dengan kebutuhan benih $3.593,73$ ton. Tahun 2018 perkembangan luas tanam kegiatan Upsus di Bali 147.496 ha dengan kebutuhan benih 3.687,4 ton Penyaluran bantuan benih inbrida padi sawah pemerintah di Bali baru mencapai 199,77 ton tahun 2018 meliputi: varietas ciherang, inpari 30, inpari 32, inpari 42 dan inpari 43 yang menggambarkan pengadaan benih oleh pemerintah masih kurang untuk memenuhi kebutuhan luas tanam sehingga peran swasta sangat dibutuhkan untuk memenuhi kekurangan benih padi di Bali.

Peran petani penangkar sangat strategis guna memenuhi penyediaan benih dalam mendukung program upaya khusus padi di Bali secara cepat pada sentra-sentra produksi padi. Produksi benih yang masih rendah dibandingkan potensi luas tanam dan jadwal tanam di setiap subak menjadi kendala, sehingga pengembangan penangkar benih melalui pemberdayaan kelompok penangkar benih yang ada di subak sangat diperlukan.

Minat tenaga kerja disektor pertanian masih rendah terutama generasi muda. Keengganan generasi muda sebagai petani padi menjadi salah satu masalah dalam memajukan bidang pertanian khususnya sebagai petani penangkar benih. Keberadaan pendamping sebagai unsur penggerak dalam meningkatkan pengetahuan, dan keterampilan petani sangat diperlukan. Pendampingan secara intensif dan berkelanjutan diperlukan untuk tujuan program perbenihan dan ketersediaan benih dalam mendukung kegiatan Upsus di Bali

Beranjak dari permasalahan tersebut, tujuan penelitian adalah 1)Menganalisis pengaruh karakteristik petani, motivasi petani dan peran pendamping terhadap perilaku petani penangkar serta pengaruhnya terhadap ketersediaan benih padi di Kabupaten Tabanan. 2)Menganalisis pengaruh karakteristik petani, motivasi petani dan peran pendamping terhadap ketersediaan benih padi melalui perilaku petania penangkar.

\section{METODE PENELITIAN}

Lokasi penelitian dilaksanakan di KUAT Subak Guama dan KUD Denbantas. Pemilihan lokasi dilakukan secara purposive sampling yaitu produsen benih dalam bentuk koperasi yang memiliki ijin produksi benih padi dengan penangkaran benih dilakukan di lahan-lahan petani dan Kabupaten Tabanan sebagai sentra produksi padi di Bali yang secara langsung memerlukan penyediaan benih padi sesuai luas tambah tanam. Waktu penelitian dilaksanakan mulai bulan Maret sampai dengan Juni 2019. Populasi penelitian adalah 142 petani-petani 
penangkar benih padi tergabung dalam KUAT Guama dan KUD Denbantas. Pengambilan sampel di masing-masing koperasi dilakukan secara stratified random sampling dengan penentuan jumlah responden dengan menerapkan rumus Slovin. Jumlah responden petani penangkar di KUAT Subak Guama sebanyak 22 orang dan di KUD Denbantas 37 orang.

Jenis data yang digunakan dalam penelitian adalah data kuantitatif dan kualitatif. Sumber data yang digunakan dalam penelitian ini meliputi sumber data primer adalah sumber data yang didapat langsung dari responden dengan kuesioner sebagai instrumen penelitian. Sumber data sekunder merupakan data yang telah diolah dan disajikan oleh pihak lain. Data sekunder dapat diperoleh dari dokumentasi, laporan resmi intansi. Variabel yang digunakan dalam penelitian ini yaitu karakteristik petani, motivasi petani, peran pendamping, perilaku petani penangkar benih dan ketersediaan benih padi Metode analisis data yang digunakan dengan analisis deskriptif untuk mendeskripsikan variabel penelitian dan analisis SEM PLS dengan bantuan program smartPLS versi 3.0

\section{HASIL DAN PEMBAHASAN}

\section{Karakteristik Petani Penangkar Benih}

Petani penangkar benih padi yang menjadi sampel penelitian sebanyak 59 orang yang berasal dari petani-petani penangkar di Subak Periyukti dan Subak Guama. Karateristik umur rata-rata petani penangkar benih padi adalah 55 tahun yang menggambarkan umur petani penangkar benih di Kabupaten Tabanan masih cukup produktif dalam melaksanakan kegiatan penangkaran benih padi.

Karakteristik pendidikan formal petani penangkar di Subak Guama dan Subak Periyukti menunjukkan memiliki latar belakang pendidikan formal setingkat Sekolah Dasar.

Karakteristik lamanya pengalaman usaha tani padi menunjukkan bahwa petani penangkar benih memiliki pengalaman usaha tani di atas 12 tahun. Rata-rata pengalaman usaha tani padi petanipetani penangkar di Subak Periyukti dan Subak Guama, Kabupaten Tabanan selama 25 tahun.

Karakteristik luas lahan garapan petani penangkar benih di Kabupaten Tabanan menunjukkan ratarata luas lahan yang digarap petani seluas 47 are. Soekartawi, 2006 menyatakan semakin luas lahan yang dikerjakan dalam usaha tani, maka akan semakin lebih besar produksi yang dihasilkan dan pendapatan yang akan diperoleh akan lebih besar bila disertai dengan pengolahan lahan yang baik.

Karakteristik pelatihan benih menunjukkan ratarata pelatihan benih yang didapat oleh petani penangkar di Kabupaten Tabanan sebanyak 2 kali. Pelatihan benih yang diperoleh petani dalam bentuk bimbingan teknis dan sekolah lapang. Menurut Mangkuprawira 2004, pelatihan merupakan sebuah proses mengajarkan pengetahuan dan keahlian serta sikap agar seseorang semakin terampil dan mampu melaksanakan tanggung jawabnya dengan semakin baik sesuai dengan standar.

Deskripsi Pengaruh Karakteristik Petani, Motivasi Petani dan Peran Pendamping Terhadap Perilaku Petani Penangkar Dalam Mendukung Ketersediaan Benih Padi di Kabupaten Tabanan

Analisis deskriptif bertujuan untuk mendeskripsikan masing-masing konstruk yang digunakan dalam penelitian yaitu karakteristik petani, motivasi petani, peran pendamping dan perilaku petani penangkar terhadap ketersediaan benih padi di Kabupaten Tabanan. Ketersediaan benih padi dengan indikator tepat varietas, tepat mutu, tepat jumlah, tepat waktu, tepat tempat dan tepat harga. Karakteristik petani dengan indikator umur, pendidikan formal, pengalaman usaha tani, luas lahan garapan, tanggungan keluarga dan pelatihan benih. Motivasi petani dengan indikator kebutuhan fisiologis, kebutuhan rasa aman, kebutuhan sosial, kebutuhan akan penghargaan dan kebutuhan aktualisasi diri. Peran pendamping dengan indikator peran pengurus subak, peran penyuluh, peran BPSBTPH, peran penangkar benih dan peran Dinas Pertanian. Perilaku petani penangkar dengan indikator pengetahuan, sikap dan keterampilan.

Motivasi kerja petani merupakan suatu alasan yang mendorong petani untuk bekerja menangkar benih. Motivasi kerja akan berdampak positif pada hasil kerja dari seseorang. Minat dan motivasi mempunyai hubungan yang erat karena motivasi merupakan penggerak dalam pencapaian sesuatu yang diinginkan. Dorongan petani di Subak Guama dan Subak Periyukti bekerja menangkar benih dalam mendukung ketersediaan benih di Kabupaten Tabanan.

Peran pendamping merupakan instansi atau pihak yang mempunyai peran dan tugas dalam kaitan dengan penyediaan benih padi di daerah seperti peran pengurus subak, peran penyuluh pertanian (PPL), peran BPSBTPH, peran penangkar dan peran Dinas Pertanian. Masing-masing mempunyai tugas dan fungsi terkait dalam ketersediaan benih padi karena program perbenihan merupakan bagian penting dalam pembangunan pertanian.

Perilaku petani penangkar yang mengerjakan penangkaran di lahan sendiri pada Subak Guama dan Subak Periyukti dilihat dari pengetahuan, sikap dan keterampilan. Pengetahuan tentang menangkar benih mencakup apa yang diketahui oleh petani terhadap cara-cara menangkar benih padi seperti pengetahuan tentang varietas padi, pengetahuan pengolahan tanah, pengetahuan tentang pengairan tanaman, pemupukan, pengendalian hama dan rouging tanaman. Sikap petani terhadap usaha tani penangkaran benih yang berasal dari diri petani terhadap stimulus 
yang didapat dari peran pendamping. Keterampilan petani menangkar benih merupakan semua kegiatan yang sudah dilakukan dalam rangka menangkar benih sebagai usaha untuk mendapatkan hasil dengan kualitas calon benih yang baik.

Usaha penangkaran benih adalah untuk mendapatkan varietas dalam jumlah, mutu, waktu, tempat dan kemurnian varietas yang terjamin sehingga diperlukan pengelolaan pertanaman maksimal. Ketersediaan benih padi merupakan tujuan pokok dari program pemerintah dalam perbenihan padi berdasarkan prinsip enam tepat yaitu tepat varietas, tepat jumlah, tepat mutu, tepat waktu, tepat lokasi dan tepat harga. Hasil capaian skor pada konstruk penelitian pada Tabel 1 berikut,

Tabel 1.Hasil Capaian Skor Pada Konstruk
Hasil pengujian outer model dalam Gambar 1 berikut

Tabel 2 Hasil Pengujian Outer Model

\begin{tabular}{|c|c|c|}
\hline Konstruk & Indikator & $\begin{array}{c}\text { Outer } \\
\text { Loading }\end{array}$ \\
\hline \multirow{6}{*}{$\begin{array}{l}\text { Karakteristik } \\
\text { Petani (KP) }\end{array}$} & Umur (KP1) & 0,799 \\
\hline & Pendidikan formal (KP2) & 0,789 \\
\hline & Pengalaman usaha tani (KP3) & 0,803 \\
\hline & Luas lahan garapan (KP4) & 0,774 \\
\hline & Tanggungan keluarga (KP5) & 0,764 \\
\hline & Pelatihan benih (KP6) & 0,630 \\
\hline \multirow{6}{*}{$\begin{array}{l}\text { Motivasi } \\
\text { Petani (MP) }\end{array}$} & Kebutuhan fisiologis (MP1) & 0,847 \\
\hline & Kebutuhan rasa aman (MP2) & 0,840 \\
\hline & Kebutuhan sosial (MP3) & 0,758 \\
\hline & $\begin{array}{l}\text { Kebutuhan akan penghargaan } \\
\text { (MP4) }\end{array}$ & 0,768 \\
\hline & & \multirow{2}{*}{0,851} \\
\hline & $\begin{array}{l}\text { Kebutuhan aktualisasi diri } \\
\text { (MP5) }\end{array}$ & \\
\hline \multirow{5}{*}{$\begin{array}{l}\text { Peran } \\
\text { Pendamping } \\
(\mathrm{PP})\end{array}$} & Peran pengurus subak (PP1) & 0,761 \\
\hline & Peran penyuluh (PP2) & 0,708 \\
\hline & Peran BPSBTPH (PP3) & 0.794 \\
\hline & Peran penangkar benih (PP4) & 0,806 \\
\hline & Peran Dinas Pertanian (PP5) & 0,777 \\
\hline \multirow{3}{*}{$\begin{array}{l}\text { Perilaku } \\
\text { Petani } \\
\text { Penangkar } \\
\text { (PPP) }\end{array}$} & Pengetahuan (PPP1) & 0,848 \\
\hline & Sikap (PPP2) & 0,805 \\
\hline & Keterampilan (PPP3) & 0,817 \\
\hline \multirow{6}{*}{$\begin{array}{l}\text { Ketersediaan } \\
\text { Benih Padi } \\
\text { (KBP) }\end{array}$} & Tepat varietas (KBP1) & 0,767 \\
\hline & Tepat mutu (KBP2) & 0,852 \\
\hline & Tepat jumlah (KBP3) & 0,802 \\
\hline & Tepat waktu (KBP4) & 0,835 \\
\hline & Tepat tempat (KBP5) & 0,782 \\
\hline & Tepat harga (KBP6) & 0,806 \\
\hline
\end{tabular}

Sumber: Data primer diolah (2019)

Hasil pengujian outer model menunjukkan masing-masing indikator pada konstruk Karakteristik Petani (KP), Motivasi Petani (MP), Peran Pendamping (PP), Perilaku Petani Penangkar (PPP) dan Ketersediaan Benih Padi (KBP) memiliki nilai loading factor lebih dari 0,70 berarti indikator dinyatakan valid untuk mengukur konstruk. Hanya indikator pelatihan benih yang memiliki nilai loading factor sebesar 0,630 namun dianggap valid untuk penelitian tahap awal dari pengembangan skala pengukuran nilai loading 0,5 sampai 0,6 dianggap cukup (Chin, 1998 dalam Ghosali, 2012) 
Discriminant validity juga bisa dinilai dengan membandingkan nilai Average Variance Extracted (AVE) setiap konstruk dengan korelasi antar konstruk dengan konstruk lainnya. Nilai AVE harus diatas 0,5 (Ghozali, 2012), Secara rinci hasil pengujian discriminant validity dalam Tabel 3 berikut

Tabel 3 Hasil Pengujian Discriminant Validity

Sumber: Data primer diolah (2019)

Reliabilitas konstruk dapat diukur melalui composit reliability dan cronbach's alpha. Ghozali (2012) mengungkapkan bahwa konstruk dinyatakan reliabel apabila nilai composit reliability dan cronbach's alpha di atas 0,70 . hasil pengujian composit reliability dan cronbach's alpha dapat dilihat pada Tabel 4 berikut

Tabel 4 Hasil Uji Composit Reliability dan Cronbach's alpha

\begin{tabular}{lcc}
\hline Konstruk & Nilai AVE & Nilai $\sqrt{\text { AVE }}$ \\
\hline KP & 0,581 & 0,762 \\
MP & 0,662 & 0,814 \\
PP & 0,593 & 0,770 \\
PPP & 0,678 & 0,823 \\
KBP & 0,653 & 0.808
\end{tabular}

Konstruk Ketersediaan Benih Padi (KBP) memiliki nilai $R$-square sebesar 0,703 menunjukkan konstruk memiliki tingkat goodness of fit yang baik yang berarti konstruk dapat dijelaskan oleh empat variabel eksogen dalam model sebesar 70,3\% dan sisanya sebesar $29,7 \%$ dijelaskan oleh konstruk lainnya yang tidak terdapat dalam model penelitian. Konstruk Perilaku Petani Penangkar (PPP) memiliki nilai $R$ square sebesar 0,676 menunjukkan bahwa konstruk dapat dijelaskan oleh ketiga variabel eksogen sebesar 67,6\% dan sisanya sebesar 32,4\% dijelaskan oleh konstruk yang lain yang tidak terdapat dalam model penelitian. Pengujian $Q$ square menunjukkan konstruk Ketersediaan Benih Padi (KBP) dan Perilaku Petani Penangkar (PPP) menunjukkan nilai $Q$ squre sebesar 0,904 artinya model mempunyai nilai relevansi prediksi yang baik.

\section{Evaluasi Koefisien Jalur (Path Coefficient)}

Pengujian hipotesis dilakukan dengan melihat nilai path coefficient untuk masing-masing konstruk untuk menguji pengaruh dari konstruk dari konstruk karakteristik petani, motivasi petani dan peran pendamping terhadap konstruk perilaku petani penangkar. Pengaruh dari konstruk karakteristik petani, motivasi petani, peran pendamping dan perilaku petani penangkat terhadap konstruk ketersediaan benih padi.

\begin{tabular}{|c|c|c|}
\hline Konstruk & Composit reliability & $\begin{array}{c}\text { Cronbach's alpRangaruh konstruk karakteristik petani, motivasi } \\
\text { petani dan peran pendamping terhadap }\end{array}$ \\
\hline KP & 0,892 & ketersediaan benih padi melalui perilaku petani \\
\hline MP & 0,907 & $\begin{array}{l}\text { penangkar. Hasil evaluasi koefisien jalur pada } \\
\text { Tabel } 4 \text { dan } 5 \text {. berikut }\end{array}$ \\
\hline
\end{tabular}

\begin{tabular}{lll} 
PPP & 0,879 & 0,829 \\
KBP & 0,863 & 0,763 \\
\hline
\end{tabular}

\section{Tabel 4 Path Coefficients}

\section{Evaluasi Model Struktural (Inner Model)}

Evaluasi model struktural dilakukan dengan melihat hasil dari nilai $R$-square $\left(R^{2}\right)$ untuk uji goodness fit konstruk dependen dan nilai $\left(Q^{2}\right)$ untuk uji predictive relevance model konstruk.Secara rinci hasil uji goodness of fit dan predictive relevance dapat dilihat pada Tabel 5 berikut

Tabel 5 Hasil Uji Goodness of fit model dan Predictive Relevance

\begin{tabular}{|c|c|c|c|}
\hline \multicolumn{3}{|c|}{ Predictive Relevance } & \multirow{2}{*}{$\begin{array}{l}\text { Sumber: Data primer diolah (2019) } \\
\text { Keterangan: t-tabel pada alpha } 5 \% \text { sebesar 2,004 }\end{array}$} \\
\hline Konstruk & $R$-Square & Q-Square & \\
\hline KBP & 0,703 & & \\
\hline PPP & 0,676 & 0,904 & \\
\hline
\end{tabular}

Sumber: Data primer diolah (2019)

Keterangan

$\mathrm{Q}^{2}=1-\left(1-\mathrm{R}^{2} \mathrm{KBP}\right) \times\left(1-\mathrm{R}^{2} \mathrm{PPP}\right)$ 
Tabel 5 Total Indirect Effects

\begin{tabular}{|c|c|c|c|c|}
\hline Konstruk & $\begin{array}{l}\text { Original } \\
\text { Sample }\end{array}$ & $t$-statistic & $P$-valu & $\begin{array}{l}\text { nilai t-statistik sebesar } 2,333 \text { (t-statistik }>\text { t-tabel } \\
\text { es,004) dan nilai } P \text {-values sebesar } 0,020<0,050 \text {. } \\
\text { Motivasi petani sebagai petani penangkar di Subak }\end{array}$ \\
\hline $\mathrm{KP}=>\mathrm{KBP}$ & $-0,047$ & 1,214 & 0,225 & $\begin{array}{l}\text { Periyukti dan Subak Guama karena dorongan } \\
\text { mensukseskan Program Seribu Desa Mandiri }\end{array}$ \\
\hline $\mathrm{MP}=>\mathrm{KBP}$ & $-0,095$ & 1,621 & 0,106 & Benih guna dapat memproduksi benih padi untuk \\
\hline $\mathrm{PP}=>\mathrm{KBP}$ & $-0,082$ & 1,003 & 0,316 & $\begin{array}{l}\text { memenuhi kebutuhan benih padi di wilay } \\
\text { sendiri dan sekitar dengan membentuk kerjasal }\end{array}$ \\
\hline
\end{tabular}

Keterangan: t-tabel pada alpha 5\% sebesar 2,004

Hasil analisis model struktural dapat dilihat pada Gambar 1 berikut

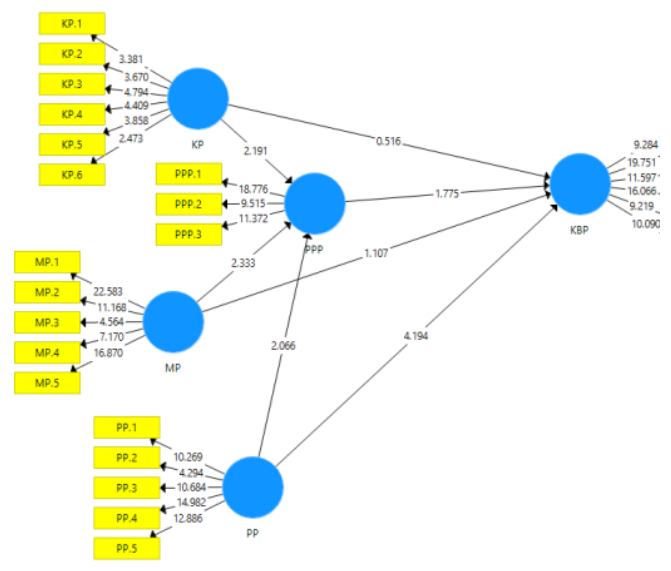

Gambar 1 Model Struktural

Secara rinci pengaruh variabel eksogen terhadap variabel endogen dapat dijelaskan sebagai berikut:

1. Pengaruh Karakteristik Petani, Motivasi Petani dan Peran Pendamping Terhadap Perilaku Petani Penangkar

Karakteristik petani berpengaruh signifikan terhadap perilaku petani penangkar di Kabupaten Tabanan. Melalui hasil koefisien jalur yang bernilai positif sebesar 0,219 dengan t-statistik sebesar sebesar 2,191 (t-statistik > t-tabel 2,004) dan nilai $P$-values sebesar $0.029<0.050$ Pada hasil penelitian ini diketahui bahwa Karakteristik petani di Subak Periyukti dan Subak Guama berpengaruh signifikan terhadap perilaku petani penangkar dalam kegiatan menangkar benih padi di lahan sendiri. Karakteristik petani dipengaruhi oleh faktor umur rata-rata petani penangkar 55 tahun merupakan umur yang masih produktif untuk bekerja, pendidikan formal masih tamat SD, pengalaman usaha tani yang lama diatas dua belas tahun, luas lahan rata-rata 47 are, tanggungan keluarga $\leq 2$ orang dan pelatihan benih rata-rata sekali

Motivasi petani menunjukkan pengaruh signifikan terhadap perilaku petani penangkar di Kabupaten Tabanan. Hal ini diperoleh melalui nilai koefisien
Peran pendamping menunjukkan pengaruh signifikan terhadap perilaku petani penangkar di Kabupaten Tabanan. Hal ini diperoleh melalui nilai koefisien jalur yang bernilai positif sebesar 0,379 dengan nilai t-statistik sebesar 2,066 (tstatistik>t-tabel 2,004) dan $P$-values sebesar 0,039 $<0,050$. Melalui hasil hasil analisis tersebut menunjukkan fungsi peran pendamping dari pengusaha benih bagi petani penangkar sangat berpengaruh terhadap perilaku petani dalam mengerjakan penangkaran benih di lahan-lahan mereka sendiri. semakin intensif peran pendampingan baik dari pemerintah, subak dan penangkar benih sebagai produsen benih padi bersertifikat dan dinas terkait maka semakin baik pengetahuan, sikap dan keterampilan petani sebagai petani penangkar benih pada Subak Guama dan Subak Periyukti.

2. Pengaruh Karakteristik Petani, Motivasi Petani, Peran Pendamping dan Perilaku Petani Penangkar Terhadap Ketersediaan Benih Padi di Kabupaten Tabanan

Perilaku petani penangkar berpengaruh tidak signifikan terhadap ketersediaan benih padi di Kabupaten Tabanan. Hal ini diperoleh dari nilai koefisien jalur bernilai negatif sebesar -0,216 dengan nilai t-statistik sebesar 1,775 (t-statistik < t-tabel 2,004) dan $P$-values sebesar 0,077 >0,050. Petani penangkar di Subak Guama dan Subak Periyukti adalah petani mengerjakan penangkaran benih di lahan sendiri sedangkan ijin produksi benih dimiliki oleh koperasi yang telah memenuhi persyaratan sebagai penangkar. Petani penangkar menjual calon benih benih kepada penangkar KUAT Guama dan KUD Denbantas untuk diproses menjadi benih bersertifikat. Calon benih yang dihasilkan oleh petani bisa diproses menjadi benih padi bersertifikat sangat tergantung dari kemampuan penangkar membeli dari petani.

Karakteristik petani berpengaruh tidak signifikan terhadap ketersediaan benih padi di Kabupaten Tabanan. Hal ini diperoleh dari nilai koefisien jalur bernilai positif sebesar 0,047 dengan nilai tstatistik sebesar 0,516 (t-statistik < t-tabel 2,004) dan $P$-values sebesar 0,606 > 0,050 Karakteristik petani sebagai ciri atau sifat nyata yang dimiliki oleh setiap petani mempengaruhi pola perilaku petani penangkar di Subak Periyukti dan Subak Guama dalam bekerja sebagai petani penangkar untuk menghasilkan calon benih kering sawah instansi pemerintah, pengurus subak, PPL dan 
yang beli oleh KUD Denbantas dan KUAT Subak Guama.

Motivasi petani berpengaruh tidak signifikan terhadap ketersediaan benih padi di Kabupaten Tabanan. Hal ini diperoleh dari nilai koefisien jalur bernilai positif sebesar 0,205 dengan nilai $t-$ statistik sebesar 1,107 (t-statistik < t-tabel 2,004) dan $P$-values sebesar 0,269>0,050. Motivasi petani sebagai dorongan untuk melakukan aktivitas pekerjaan usaha tani penangkaran untuk menghasilkan calon benih dari varietas dan kelas benih tertentu. Ketersediaan benih ditentukan oleh kemampuan penangkar untuk membeli dan mengolah calon benih menjadi benih bersertifikat.

Peran pendamping berpengaruh signifikan terhadap ketersediaan benih padi di Kabupaten Tabanan. Hal ini diperoleh dari nilai koefisien jalur bernilai positif sebesar 0,815 dengan nilai tstatistik sebesar 4,194 (t-statistik > t-tabel 2,004) dan $P$-values sebesar $0,000<0,050$ Tugas dan fungsi masing-masing peran pendamping yang mempengaruhi ketersediaan benih. Penangkar sebagai lembaga usaha yang memproduksi benih bersertifikat setelah melalui tahapan proses pengujian lapangan dan laboratorium dari BPSBTPH.

3. Pengaruh Karakteristik Petani, Motivasi Petani dan Peran Pendamping Terhadap Ketersediaan Benih Padi di Kabupaten Tabanan Melalui Perilaku Petani Penangkar

Karakteristik petani berpengaruh tidak signifikan terhadap ketersediaan benih padi melalui perilaku petani penangkar Hal ini diperoleh dari nilai koefisien jalur bernilai negatif sebesar $-0,047$ dengan nilai t-statistik sebesar 1,214 (t-statistik $<\mathrm{t}$ tabel 2,004) dan P-values sebesar 0,225 > 0,050. Benih yang dihasilkan oleh petani penangkar adalah Calon Benih Kering Sawah (CBKS) sesuai varietas dan kelas benih tertentu. Pengolahan benih seperti pemilahan (grading), pembersihan benih, proses pengeringan dikerjakan oleh penangkar/produsen benih.

Motivasi petani berpengaruh tidak signifikan terhadap ketersediaan benih padi (KBP) melalui perilaku petani penangkar. Hal ini diperoleh dari nilai koefisien jalur bernilai negatif sebesar $-0,095$ dengan nilai t-statistik sebesar 1,621 (t-statistik $<\mathrm{t}$ tabel 2,004) dan $P$-values sebesar 0,106>0,050. Motivasi petani adalah dorongan untuk bekerja sebagai petani penangkar. dorongan mengarahkan seseorang pada mekanisme berperilaku. Motivasi petani akan mempengaruhi petani dalam usaha tani ke arah yang lebih baik.

Peran pendamping berpengaruh tidak signifikan terhadap ketersediaan benih padi melalui perilaku petani penangkar. Hal ini diperoleh dari nilai koefisien jalur bernilai negatif sebesar $-0,082$ dengan nilai t-statistik sebesar 1,003 (t-statistik $<\mathrm{t}$ tabel 2,004) dan $P$-values sebesar 0,316>0,050.
Petani penangkar dalam usaha tani penangkaran di lahan sendiri menghasilkan calon benih dari varietas dan kelas benih yang ditangkarkan. Proses pengolahan benih menjadi benih padi bersertifikat sangat ditentukan oleh kemampuan penangkar KUD Denbantas dan KUAT Guama dalam membeli/mengopkoop calon benih kering sawah dari petani penangkar di Subak Periyukti dan Subak Guama

\section{SIMPULAN DAN SARAN}

\section{Simpulan}

Berdasarkan hasil analisis dan pembahasan yang telah dilakukan dalam penelitian ini dapat diperoleh simpulan sebagai berikut: (1) Karakteristik petani, motivasi petani dan peran pendamping berpengaruh signifikan terhadap perilaku petani penangkar dalam mengerjakan penangkaran benih padi di lahan-lahan sendiri; (2) Karakteristik petani, motivasi petani dan perilaku petani penangkar berpengaruh tidak signifikan terhadap ketersediaan benih padi bersertifikat; (3) Peran Pendamping berpengaruh signifikan terhadap ketersediaan benih padi bersertifikat.; (4) Karakteristik petani, motivasi petani dan peran pendamping berpengaruh tidak sigifikan terhadap ketersediaan benih padi bersertifikat melalui perilaku petani penangkar.

\section{Saran}

Saran yang dapat diberikan terkait dengan ketersediaan benih padi dengan prinsip 6 tepat yang dilakukan di wilayah Kabupaten Tabanan sebagai berikut: (1) Untuk menjaga ketersediaan benih padi di Kabupaten Tabanan maka peran masing-masing pendamping yaitu kelembagaan perbenihan dalam mendampingi petani penangkar benih di lahan-lahan sendiri harus dioptimalkan sesuai dengan tugas dan fungsi masing-masing pendamping; (2) Peran pendamping dalam mendampingi petani penangkar lebih dioptimalkan adalah peran subak, PPL, BPSBTPH, Produsen benih, dan Dinas Pertanian di wilayah penangkaran benih sehingga ketersediaan benih dengan 6 tepat (tepat varieras, tepat mutu, tepat waktu, tepat jumlah, tepat tempat dan tepat harga) bisa tercapai; (3) Meningkatkan kemampuan penangkar lokal untuk mengopkoop calon benih yang dihasilkan oleh petani-petani penangkar agar dapat diproses menjadi benih bersertifikat.

\section{DAFTAR PUSTAKA}

Aryawan, 2013 Peran Subak dalam Aktivitas Pertanian Padi Sawah (Kasus di Subak Dalem, Kecamatan Kerambitan, Kabupaten Tabanan). E-Jurnal Agribisnis dan Agrowisata Vol.2, No.1, Januari 2013 Denpasar: Unud

Ayu Citra Laksmi, 2017. Strategi Pengembangan Usaha Perbenihan Padi Bersertifikat di 
Subak Guama Kecamatan Marga Kabupaten Tabanan, Jurnal Manajeman Agribisnis Vol. 5, No. 1, Mei 2018. Denpasar: Unud

Atang. M. Safei, Yati Haryati, Bebet Nurbaeti, 2016. Pengaruh Karakteristik Individu Terhadap Tingkat Pengetahuan dan Sikap Petani Pada Produksi Benih Padi di Kabupaten Indramayu. Buletin Hasil Kajian Vol.6 Tahun 2019. Balai Pengkajian Teknologi Pertanian Jawa Barat.

BPSBTPH Provinsi Bali. 2012. Realisasi Sertifikasi Benih Padi Non Hibrida Tahun 2011. Denpasar: BPSBTPH Bali.

Darman, M. Arsyad dan Maesti, M. 2007. Pemberdayaan Kelompok Tani Sebagai Penangkar Benih Padi dan Palawija. Prosiding Lokakarya Regional Akselerasi Diseminasi Inovasi Teknologi Pertanian Mendukung Pembangunan Berawal dari Desa. Bogor: Balai Besar Pengkajian dan Pengembangan Teknologi Pertanian (BBP2TP).

Ghozali, I. 2012. Structural Equation Modeling Metode Alternatif dengan Partial Least Square. Edisi 3. Semarang: Universitas Diponogoro.

Karunianingtias, H. 2005. Perilaku Pertani Terhadap Pemupukan Berimbang Pada Tanaman Padi Sawah. (skripsi) Denpasar: Jurusan Sosial Ekonomi Pertanian Fakultas Pertanian. Universitas Udayana.

Mangkuprawira, S. 2004. Manajemen Sumber Daya Manusia Strategik. Ghalia Indonesia: Bogor.

Martey, 2015. Impact of Farmer Mentorship Project on Farm Efficiency and Income Rural Ghana. Journal of Agriculture Science 09(September) 79-93

Maslow, A.1994 Motivasi dan Kepribadian I. Jakarta: Pustaka Binaman Pressindo.

Mosher, AT. 1965. Menggerakkan dan Membangun Pertanian. Krisnandi S: penyadur. Jakarta.

Mislini, 2006. Analisis Jaringan Komunikasi pada Kelompok Swadaya Masyarakat. Kasus KSM di Desa Taman Sari Kabupaten Bogor, Provinsi Jawa Barat. (tesis). Bogor. Program Pascasarjana, Institut Pertanian Bogor.
Nugraha, U.S., S. Wahyuni, M.Y. Samaullah, dan A. Ruskandar. 2007. Sistem Perbenihan Padi. Balai Besar Penelitian Tanaman Padi.

Nugraha. 2008 End of Mission Report of National Consultan on Seed Production Accelerated Training on Improved Rice Production Technologiesin Support to the Presidential Initiative to increase Rice Production by 2 Million Tonnes (TCP/INS/3102(D), Jakarta FAOIndonesia.

Pribadi Yanuar. 2016. Analisis Dampak dan Efektivitas Pendampingan Terhadap Adopsi Teknologi PTT dan Produktivitas Padi Sawah di Kecamatan Gambut Kabupaten Banjar Kalimantan Selatan. Prosiding Semnas Inovasi Teknologi Pertanian. Banjarbaru.

Digna, Joel dan David, 2013. Membangun Sistem Perbenihan Berbasis Masyarakat Manual Pelatihan. Bogor: Pusat Penelitian dan Pengembangan Tanaman Pangan

Syafitri. 2018. Peran Mediasi Pendampingan Pada Pengaruh Karakteristik Petani Terhadap Produktivitas Petani Penangkar Benih Padi Kabupaten Bantul, (skripsi) Yogyakarta: Program Studi Manajeman Universitas Sanata Darma.

Soekartawi. 2006. Prinsip Dasar Ekonomi Pertanian Teori dan Aplikasi. Edisi Revisi. Jakarta.

Soeparno, S. 2002. Sosiologi Suatu Pengantar. Jakarta: Raja Grafindo Persada.

Suastika. 2017. Laporan Akhir Tahun Produksi Benih Sumber Padi 16 Ton ES. Denpasar: Balai Pengkajian Teknologi Bali .

Sutami. 2016. Upaya dan Kendala Penyediaan Benih Padi dari Pemerintah dan Petani Penangkar Mendukung Kedaulatan Pangan di Propinsi Bali. Prosiding Semnas Inovasi Teknologi Pertanian Banjarbaru. Balai Pengkajian Teknologi Pertanian Bali

Syafitri. 2018. Peran Mediasi Pendampingan Pada Pengaruh Karakteristik Petani Terhadap Produktivitas Petani Penangkar Benih Padi Kabupaten Bantul, (skripsi). Yogyakarta: Program Studi Manajeman Universitas Sanata Darma. 